\title{
JOANNA WALISZEWSKA
}

Uniwersytet im. Adama Mickiewicza w Poznaniu

\section{ANTROPONIMY I TOPONIMY W ŁUŻYCKICH TŁUMACZENIACH EWANGELII WEDEUG ŚW. MATEUSZA}

\section{Wstęp}

Celem niniejszego artykułu jest opis i interpretacja różnic z zakresu antroponimii i toponimii w dwóch katolickich górnołużyckich przekładach Ewangelii według św. Mateusza.

Podstawą materiałową artykułu są następujące wydania Biblii:

1. Swjate Pismo Noweho zakonja, Budyšin 1966 (SP 1966);

2. Swjate Pismo Stareho a Noweho zakonja, Budyšin 2006 (SP 2006).

Wyekscerpowane antroponimy i toponimy porównano między sobą oraz $\mathrm{z}$ formami z poniższych wydań Biblii:

1. Bible svatá aneb všecka svatá pisma starého i nowého zakona, podle posledního vydání kralického z roku 1613 (przekład protestancki) (B 1613);

2. Nowy zakoń, przeł. J. Łusčanski, M. Hórnik, Budyšin 1896 (przekład katolicki) (NZ 1896);

3. Biblia, to je Zyle Sswjate Pifzmo ftareho a noweho fakonja, Budyšin 1905 (B 1905);

4. Sćenje po swjatym Mateju, Budyšin 1960 (zrewidowany przekład protestancki) (SM 1960);

5. Das neue Testament, Revidierte Erbelfelder Übersetzung, Wuppertal 1975 (przekład protestancki) (NT 1975).

6. Die Bibel im heutigem Deutsch. Die Gute Nachricht des Alten und Neuen Testaments, Liechtenstein 1994 (przekład katolicki) (B 1994);

W rozdziale pierwszym przedstawiam krótko historię łużyckich przekładów Biblii. Rozdział drugi poświęcony jest analizie różnic postaci językowej nazw własnych w katolickich edycjach Ewangelii wedtug świętego Mateusza. Skorzystałam w nim z odpowiedniej literatury dotyczącej problematyki onomastycznej w przekładach (Biolik red. 1993; Kania, Tokarski 1984; Ginter 2008) oraz z opracowań sorabistycznych poświęconych piśmiennictwu biblijnemu (Lewaszkiewicz 1998; Lewaszkiewicz 1995; Siatkowska, Meškank 2001). 


\section{Zarys historii łużyckich przekładów Biblii}

(na podstawie: Lewaszkiewicz 1998; Lewaszkiewicz 1995)

\subsection{Uwagi wstępne}

Piśmiennictwo łużyckie do połowy XIX wieku rozwijało się głównie dzięki tekstom religijnym oraz przekładom biblijnym. Po wystąpieniu Marcina Lutra na Łużycach doszło do rozłamu religijnego. Ruch reformacyjny objął całe Dolne Łużyce, wypierając katolicyzm; protestantyzm objął do roku 1580 prawie cały teren Górnych Łużyc. Religia katolicka utrzymywała się jedynie na nieznacznym obszarze na zachód od Budziszyna, w okolicach Kamjenca, Radwora i Kulowa.

Protestantyzm przyczynił się do rozwoju łużyckiego piśmiennictwa dzięki zwolennikom reformy Marcina Lutra, głoszącym potrzebę popularyzacji zasad wiary w językach narodowych. Przekład Nowego Testamentu Mikławša Jakubicy, gotowy w 1548 roku, nie został jednak wydany. W roku 1595 została wydrukowana pierwsza górnołużycka książka: Katechizm Wjacława Warichiusa. W XVII stuleciu na Dolnych i Górnych Łużycach powstawały rękopiśmienne przekłady fragmentów Pisma Świętego, thumaczono również pieśni religijne oraz modlitwy.

Do końca XVII wieku pisano na Łużycach jedynie w miejscowych dialektach. W tym okresie w formowaniu języka literackiego uczestniczyli niemal wyłącznie protestanci. Pierwszy katolicki druk ukazał się najprawdopodobniej w 1659 roku, choć teksty rękopiśmienne powstawały znacznie wcześniej.

Na przełomie XVII i XVIII wieku w łużyckim piśmiennictwie dominowały trzy dialekty: budziszyński, kulowski i chociebuski. Górnołużycki język literacki protestantów rozwijał się w oparciu o dialekt budziszyński. Podstawą jego rozwoju były przekłady tekstów biblijnych Michała Frencla $z$ lat 1670-1706 ${ }^{1}$. Odegrał on ważną rolę w historii górnołużyckiego piśmiennictwa protestanckiego, stwarzając jako pierwszy wzór języka literackiego. $\mathrm{Na}$ dialekcie kulowskim, inaczej zachodnio-górno-łużyckim, oparli się katolicy górnołużyccy. Jego kodyfikacja nastąpiła za sprawą gramatyki Jakuba Ticina z roku 1679, posłużył się nim w tekstach religijnych Jurij Hawšyn Swětlik². Dialekt chociebuski stał się podstawą piśmiennictwa dolnołużyckiego za sprawą Nowego Testamentu Jana Bogumiła Fabriciusa z 1709 roku. Wskutek dominacji tychże dialektów w XVIII wieku na Łużycach funkcjonowały trzy różne warianty łużyckiego języka literackiego: dolnołużycki oraz katolicki i protestancki wariant górnołużyckiego. Istniejąca na Górnych Łużycach dychotomia wynikała z podziału religijnego, zwłaszcza że obydwie grupy zamieszkiwały różne tereny.

Po roku 1840 zawiązał się ruch tak zwanego łużyckiego odrodzenia narodowego. Jego głównym zadaniem było zniesienie językowego dualizmu w górnołużyckim piśmiennictwie. Zadania kodyfikacji jednolitego języka górnołużyckiego pod względem leksyki, gramatyki, wymowy i pisowni (nazywanej analogiczną, przez wzgląd na odwołanie się do czeskiej) podjął się Křesćan Bohuwěr Pful. Zasady nowej pisowni przyjęli bez oporu wy-

\footnotetext{
${ }^{1}$ Wspomniane przekłady to wydane w 1670 r. Ewangelie wedtug Mateusza i Marka, Listy do Rzymian i Galatów z 1693 roku i Nowy Testament z 1706 roku.

2 J.H. Swětlik przetłumaczył Perykopy, całą Biblię (istnieje w rękopisie), wydał teksty religijne oraz słownik łacińsko-górnołużycki (1721) i kilka rozpraw dotyczących pisowni i fonetyki.
} 
dawcy religijnej prasy katolickiej i Jurij Łusčanski oraz Michał Hórnik - thumacze Nowego Testamentu (1896). Wprowadzenie pisowni analogicznej spotkało się z dużym oporem ze strony duchowieństwa protestanckiego, które nie chciało zrezygnować z tradycyjnej pisowni biblijnej. Być może obawiano się wzrostu znaczenia łużyckich katolików w ruchu odrodzenia narodowego.

\subsection{Górnołużyckie przekłady redakcji protestanckiej}

Pierwsza górnołużycka książka, będąca tłumaczeniem Katechizmu Lutra - Katechizm Wjacława Warichiusa (1595) - zawiera fragmenty Biblii; Psalmy pokutne H. Martiniego są już typowym biblijnym przekładem, opierały się jednak na tekście niemieckim. Przełomem w dziedzinie górnołużyckiego piśmiennictwa protestanckiego stała się działalność Michała Frencla, który przełożył Ewangelię wedtug św. Mateusza i Marka (1670). Swoje thumaczenie M. Frencel oparł na Biblii Lutra, tekście greckim, czeskim oraz polskim. Cała Biblia protestancka została wydana w 1728 roku przez czterech pastorów - Jana Běmara, Mateja Jokuša, Jana Langa i Jana Wawera. Opierali się oni na tekście Lutra i tekście greckim, dokonali również porównania z tłumaczeniem czeskim, polskim i słoweńskim.

\subsection{Górnołużyckie przekłady redakcji katolickiej}

Pierwszą publikacją katolicką są Historie biblijne (1659). W 1685 roku Jakub Ticin wydał Katechizm Petrusa Canisiusa, miał w planach również tłumaczenie części Biblii, porzucił jednak swój zamiar. Osobą, która w największym stopniu przyczyniła się do rozwoju katolickiego wariantu języka górnołużyckiego, był Jurij Hawštyn Swětlik poprzez wydanie Perykop w 1690 roku. Na ich podstawie opracował w 1721 roku Stownik łacińsko-górnołużycki, który w zamyśle był przeznaczony dla księży: miał pomóc im w zrozumieniu bardziej skomplikowanych fragmentów Biblii. Pełny przekład Nowego Testamentu ukazał się dopiero w 1896 roku za sprawą J. Łusčanskiego i M. Hórnika.

\section{Analiza nazw własnych w dwóch edycjach katolickiego przekładu Biblii (Ewangelii wedlug świętego Mateusza z 1966 roku i z 2006 roku)}

\subsection{Onomastyka przekładów biblijnych}

Biblia, ze względu na zawarte w niej bogactwo i różnorodność gatunków literackich, od dawna stanowi przedmiot zainteresowań literaturoznawców oraz językoznawców. Nazwy własne analizowano przez wzgląd na ich „kształt morfologiczny, odmianę, etymologię, śledzono rozpowszechnienie imion o biblijnym rodowodzie służących do nominacji. Mamy już wiele $\operatorname{prac}^{3}$ omawiających etnonimy, habitativa, monograficzne opracowania

\footnotetext{
3 Jak zaznacza Maria Kamińska, na szczególną uwagę zasługują opracowania ks. A. Klawka.
} 
niektórych antroponimów” (Kamińska 1993: 321). Warto w tym miejscu zacytować pogląd Marii Kamińskiej:

Tłumaczenia na języki narodowe zwielokrotniają problematykę tekstu, wzbogacając ją o zagadnienia translacji, a jednocześnie powodują wielokierunkowy wpływ tekstu na literatury i języki Europy. [...] Ważnym elementem związanym z nazwami własnymi są próby wyjaśnienia ich etymologii. Dociekania etymologiczne stanowią bardzo znamienny rys ksiąg biblijnych, niektóre spośród nich przynoszą rzeczywiste wytłumaczenie nazwy własnej, inne stanowią przykłady etymologii ludowej. [...] W opinii wielu językoznawców nieprzetłumaczalność jest wyróżniająca cechą nazw własnych, ale [...] osobliwa pozycja imion, miejsc i ludzi w kulturze Izraela, ich względna żywotność powoduje często konieczność sięgnięcia po interpretację imienia i jego przekład. Trzeba także oddać przy pomocy języka translacji formy pochodne od nazw własnych. Zdarza się tak, że nazwę własną jeden translator oddaje przez nomen proprium, inny tę samą przez apellativum, okazuje się w konsekwencji, że bilans nazw własnych oryginału różni się od odpowiednich danych przekładu, a i poszczególne przekłady na ten sam język różnią się między sobą. Jednowyrazowe nomen proprium oddaje się niekiedy $\mathrm{w}$ języku thumaczenia przez wielowyrazowe kombinacje, co także zmienia pozycję nazwy własnej (Kamińska 1993: 321-323).

Z jednej strony, jak pisze Mieczysław Basaj, „stosunek do antroponimów jest inny z punktu widzenia języka niż z punktu widzenia literatury. $Z$ językoznawczego punktu widzenia antroponimy są nienacechowane i służą wyłącznie do oznaczania osoby" (Basaj 1993: 337), jednak ,imiona biblijne żyją niejako swoim życiem, poza tekstem ewangelicznym. Stają się znakiem określonych postaw, zyskują dodatkową konotację" (Umińska-Tytoń 1993: 329). Stąd właśnie wynikają trudności związane z przekładalnością nazw własnych występujących $\mathrm{w}$ tekstach biblijnych. Tłumacz staje przed problemem dominanty swojego przekładu - czy przybliżyć czytelnikowi antroponimy i toponimy poprzez znalezienie formy w jego ojczystym języku, czy odwołać się do tradycji i opierać na wcześniejszych wersjach tekstu.

\subsection{Prezentacja i analiza materiału onomastycznego}

Formy podaję w następującym porządku: wydanie nowsze z 2006 roku, oznaczone jako SP 2006 (Swjate Pismo 2006), następnie wydanie starsze z 1966 roku - SP 1966 (Swjate Pismo 1966) w kolejności występowania w tekście. Jeżeli dana forma występowała w tekście Ewangelii wedtug św. Mateusza kilkakrotnie, w przypisie oznaczam jedynie jej pierwszy zapis. Jeśli dana nazwa występuje w przypadku zależnym, to najpierw podaję mianownik liczby pojedynczej, a po dwukropku formę występującą w tekście, np. (SP 2006) Aminadab: spłodźi Aminadaba.

\subsubsection{Antroponimy}

(SP 2006: 1087) Perec, Serach: spłodźi Pereca a Serachu - (SP 1966: 16) Fares, Sara: spłodźi Faresa a Saru;

(SP 2006: 1087) Perec - (SP 1966: 16) Fares:

Formy Perec oraz Serachu nie są notowane w żadnym z łużyckich przekładów, pojawiają się za to w niemieckim przekładzie katolickim (B 1994: 3) (Perez und Serach) oraz 
protestanckim (NT 1975: 1) (Perez und Serah). Fares występuje w tłumaczeniu Hórnika (NZ 1896: 1) oraz Frencla (SM 1960: 5). Zauważa się analogię do tłumaczenia protestanckiego Farez oraz czeskiego wariantu Fáres (B 1613: 3). Antroponim Saru jest zbieżny z tłumaczeniem wariantu protestanckiego języka górnołużyckiego z 1905 roku (B 1905: 1) oraz z przekładem Frencla (SM 1960: 5). Forma ta nawiązuje do formy występującej u Hórnika Zaru (NZ 1896: 1) czeskiej Záru (B 1613: 3).

(SP 2006: 1087) Hecron: spłodźi Hecrona - (SP 1966: 16) Esron: spłodźi Esrona; (SP 2006: 1087) Hecron - (SP 1966: 16) Esron:

Antroponim Hecron nawiązuje do Hesroma, występującego w tłumaczeniu Frencla (SM 1960: 5), oraz do niemieckich przekładów - katolickiego (B 1994: 3) i protestanckiego (NT 1975: 1) (identyczna forma Hezron). Esron występuje w przekładach Hórnika (NZ 1896: 1), tekście łużyckim z 1905 roku (B 1905: 1), widoczne jest podobieństwo do czeskiego Ezroma (B 1613: 3).

(SP 2006: 1087) Aminadab: spłodźi Aminadaba- (SP 1966: 16) Amminadab: spłodźi Amminadaba;

(SP 2006: 1087) Aminadab - (SP 1966: 16) Amminadab:

Pisownia imienia Aminadab jest zbieżna z formami występującymi w przekładach Hórnika (NZ 1896: 1), Frencla (SM 1960: 5), w łużyckim zrewidowanym przez Jakuba Jurija (B 1905: 1) oraz w thumaczeniu czeskim (B 1613: 3) i w protestanckim przekładzie na język niemiecki (NT 1975: 1). Pisownia Amminadab zgadza się z antroponimem użytym w katolickiej redakcji niemieckiej Biblii (B 1994: 3).

(SP 2006: 1087) Nachšon: spłodźi Nachšona - (SP 1966: 16) Naason: spłodźi Naasona; (SP 2006: 1087) Nachšon - (SP 1966: 16) Naason:

Zapis Nachšon zdaje się opierać na występującej w niemieckim przekładzie redakcji katolickiej formie Nachschon (B 1994: 3) mniejsze podobieństwo zachodzi w stosunku do redakcji protestanckiej (Nahesson) (NT 1975: 1). Antroponim Naason nawiązuje bardziej do Frencla (Naason) (SM 1960: 5) i częściowo do Hórnika (Naasson) (NZ 1896:1). Podobna forma występuje w czeskim tłumaczeniu - Názon (B 1613: 3). W tekście łużyckim z 1905 roku poświadczony jest zapis Nahafzona, Nahafzon (B 1905: 1).

(SP 2006: 1087) Boaz: spłodźi Boaza - (SP 1966: 16) Booz: spłodźi Booza;

(SP 2006: 1087) Boaz - (SP 1966: 16) Booz:

Przy formie Boaz zauważa sie nawiązanie do wariantu występującego w tłumaczeniu łużyckim z 1905 roku (Boaš) (B 1905: 1) oraz niemieckich zapisów: Boas (B 1994: 3, NT 1975: 1); u Frencla jest poświadczone imię Boes (SM 1960: 5). Z kolei przekład starszy, w którym występuje antroponim Booz, czerpie z przekładu Hórnika (Booz) (NZ 1896: 1) oraz czeskiego Bóz (B 1613: 3).

(SP 2006: 1087) Izai: spłodźi Izaija - (SP 1966: 16) Jesse: sptodźi Jessea, (SP 2006: 1087) Izai - (SP 1966: 16) Jesse:

Imię Izai ani żadna jego analogiczna forma nie występuje w tłumaczeniach łużyckich oraz czeskich. Jest natomiast notowane w niemieckim przekładzie wariantu katolickie- 
go - Isai (B 1994:3). Antroponim Jesse został bezpośrednio zaczerpnięty od Hórnika (NZ 1896: 1) lub protestanckiej redakcji niemieckiego thumaczenia (NT 1975: 1); zauważalne jest podobieństwo do formy użytej w tekście z 1905 roku Ješe (B 1905:1) oraz czeskiego Jese (B 1613: 3). Frencel wprowadza formę Jesaj (SM 1960: 5).

(SP 2006: 1087) Salomo - (SP 1966: 16) Salomon:

Antroponim Salomo występuje jedynie w niemieckich przekładach, zarówno redakcji katolickiej (B 1994: 3), jak i protestanckiej (NT 1975: 1), nie odnotowuje się go jednak w żadnym z łużyckich tłumaczeń. Imię Salomon jest odnotowane w tłumaczeniach Hórnika (NZ 1896: 1) i z 1905 roku (B 1905: 1), zauważa się nieznaczną analogię do czeskiego Šalomoun (B 1613: 3). Frencel w swoim przekładzie przyjął formę Salmon (SM 1960: 5).

(SP 2006: 1087) Rehabeam: spłodźi Rehabeama - (SP 1966: 16) Roboam: spłodźi Roboama,

(SP 2006: 1087) Rehabeam - (SP 1966: 16) Roboam:

Występująca w katolickim przekładzie z 2006 roku forma Rehabeam została zaczerpnięta z dwóch przekładów niemieckich (B 1994: 3, NT 1975: 1); w tłumaczeniach łużyckich nie występuje. Antroponim Roboam jest poświadczony u Hórnika (NZ 1896: 1), Frencla (SM 1960: 5), w tekście z 1905 roku (B 1905: 1); zachowano podobieństwo do czeskiego Roboám (B 1613: 3).

(SP 2006: 1087) Abija: spłodźi Abiju - (SP 1966: 16) Abias: spłodźi Abiasa;

(SP 2006: 1087) Abija - (SP 1966: 16) Abias:

Abija nawiązuje bezpośrednio do niemieckiego przekładu redakcji katolickiej (B 1994: 3); w wersji protestanckiej występuje Abia (NT 1975: 1), tak jak w thumaczeniu zrewidowanym przez Jurija Jakuba (B 1905: 1). Formę Abias odnotowują przekłady Hórnika (NZ 1896: 1) i Frencla (SM 1960: 5); nawiązuje ona do czeskiego Abiáš (B 1613: 3).

(SP 2006: 1087) Aza: sptodźi Azu - (SP 1966: 16) Asa: spłodźi Asu;

(SP 2006: 1087) $\boldsymbol{A z a}$ - (SP 1966: 16) Asa:

Antroponim $A z a$ jest odnotowany jedynie w czeskim thumaczeniu (B 1613: 3). Formę Asa zastosowano w przekładzie Hórnika (NZ 1896: 1) oraz obydwóch niemieckich (B 1994: 3, NT 1975: 1); u Frencla występuje Asaf (SM 1960: 5), a w thumaczeniu z 1905 roku $A \check{s} a$ (B 1905: 1).

(SP 2006: 1087) Jošafat: spłodźi Jošafata - (SP 1966: 16) Jozafat: spłodźi Jozafata;

(SP 2006: 1087) Jošafat - (SP 1966: 17) Jozafat:

Pisownia imienia Jošafat nawiązuje do występującej w niemieckim przekładzie redakcji katolickiej Joschafat (B 1994: 3) (wersja protestancka - Josaphat (NT 1975: 1). Częściowo odwołuje się do zapisu Josafat odnotowanego w thumaczeniu Hórnika (NZ 1896: 1) oraz w zrewidowanym przez Jurija Jakuba (B 1905: 1). Natomiast Jozafat jest tożsamy z antroponimem użytym w przekładzie czeskim (B 1613: 3). U Frencla występuje zapis Josafat, Josafata (SM 1960: 5).

(SP 2006: 1087) Uzija: spłodźi Uziju - (SP 1966: 17) Ozias: spłodźi Oziasa; 
(SP 2006: 1087) Uzija - (SP 1966: 17) Ozias:

Występujące $\mathrm{w}$ niemieckich przekładach antroponimy Usija (redakcja katolicka (B 1994: 3)) oraz Usia (redakcja protestancka (NT 1975: 1)) wpłynęły prawdopodobnie na formę Uzij, która nie została poświadczona w innych łużyckich tłumaczeniach. Zapis Ozias jest tożsamy z imieniem występującym w translacji Hórnika (NZ 1896: 1). Nawiązuje częściowo do użytego w tekście z 1905 roku Hosiaša (B 1905: 1), Frenclowskiego Ociasa (SM 1960: 5)i czeskiego Oziáše (B 1613: 3).

(SP 2006: 1087) Jotam: splodźi Jotama - (SP 1966: 17) Joatam: spłodźi Joatama;

(SP 2006: 1087) Jotam - (SP 1966: 17) Joatam:

Zastosowany w łużyckim przekładzie zapis Jotam jest zgodny z thumaczeniem niemieckim redakcji katolickiej (B 1994: 3) (tekst protestancki - Jotham (NT 1975: 1)). Antroponim Joatam odwołuje się bezpośrednio do wersji Frencla (SM 1960: 5) oraz częściowo do formy Joatham (Hórnik (NZ 1896: 1) oraz przekład z 1905 roku (B 1905: 1)); zachodzi znaczne podobieństwo do czeskiego Joátam (B 1613: 3).

(SP 2006: 1087) Ahas: spłodźi Ahasa - (SP 1966: 17) Achaz: sptodźi Achaza;

(SP 2006: 1087) Ahas - (SP 1966: 17) Achaz:

Imię Ahas jest zgodne z zapisem przyjętym przez thumaczy Biblii niemieckiej redakcji katolickiej (B 1994: 3) oraz protestanckiej (NT 1975: 1). Użyte w thumaczeniu z 1966 roku Achaz odwołuje się do tłumaczenia Hórnika (również Achaz) (NZ 1896: 1), częściowo także do Frencla (Achac) (SM 1960: 5). Antroponimy Achaš (tłumaczenie z 1905 roku (B 1905: 1)) i Achas (przekład czeski (B 1613: 3)) sytuują się pomiędzy łużyckimi formami Ahas - Achaz.

(SP 2006: 1087) Hiskija: spłodźi Hiskiju - (SP 1966: 17) Ezechias: spłodźi Ezechiasa; (SP 2006: 1087) Hiskija - (SP 1966: 17) Ezechias:

Antroponim Hiskija jest tożsamy z występującym w niemieckim przekładzie redakcji katolickiej i częściowo nawiązuje do wersji protestanckiej (Hiskia) (NT 1975: 1). Identyczna forma nie została użyta w żadnym innym tłumaczeniu łużyckim ani czeskim (B 1613: 3), a do zapisu użytego przez Frencla - Hecekias (SM 1960: 5) - w znacznie większym stopniu odwołuje się łużycki Ezechias z 1966 roku. Imię Ezechias pojawia się u Hórnika (NZ 1896:1), pokrewna forma Ezechiaš została zapisana w tekście łużyckim z 1905 roku (B 1905: 1) oraz w przekładzie czeskim (Ezechiáś) (B 1613: 3).

(SP 2006: 1087) Manasse: spłodźi Manassu - (SP 1966: 17) Manases: spłodźi Manasesa; (SP 2006: 1087) Manasse - (SP 1966: 17) Manases:

Forma imienia Manasse pojawia się jedynie w przekładach niemieckich, zarówno redakcji katolickiej (B 1994: 3), jak i protestanckiej (NT 1975: 1). Antroponim Manases występujący w tłumaczeniu łużyckim z 1966 roku - pokrywa się jedynie z zapisem przyjętym przez Frencla (SM 1960: 5). Formy Manasses (Hórnik (NZ 1896: 1)) i Manasses (przekład czeski (B 1613: 3)) sytuują się pomiędzy dwoma najnowszymi przekładami łużyckimi: trudno określić, która $\mathrm{z}$ form - Manasse czy Manases - jest im bliższa. W stosunku do zapisu Manašeš (tekst łużycki zrewidowany przez Jurija Jakuba (B 1905: 1)) bardziej adekwatny wydaje się antroponim Manases. 
(SP 2006: 1087) Jošija: spłodźi Jošiju - (SP 1966: 17) Jozias: spłodźi Joziasa;

(SP 2006: 1087) Jošija - (SP 1966: 17) Jozias:

W niemieckim thumaczeniu redakcji katolickiej występuje antroponim Joschija (B 1994: 3), w stosunku do którego zachodzi znaczne podobieństwo łużyckiej formy Jošija; protestanckiemu odpowiednikowi tegoż (NT 1975: 1) (forma podstawowa: Josia) bliższy jest wariant Jozias z 1966 roku. W pozostałych przekładach łużyckich pojawiają się formy, w stosunku do których większe podobieństwo zachodzi ze strony starszej formy (tj. Jozias): Josias (Hórnik (NZ 1896:1), Frencel (SM 1960: 5)), Jofiafz (tekst łużycki z 1905 roku (B 1905: 1)). Podobna sytuacja ma miejsce w przypadku thumaczenia czeskiego Joziáš (B 1613: 3).

(SP 2006: 1087) Jojachin: spłodźi Jojachina - (SP 1966: 17) Jechonias: sptodźi Jechoniasa;

(SP 2006: 1087) Jojachin - (SP 1966: 17) Jechonias:

Antroponim Jojachin występuje jedynie w niemieckich tłumaczeniach redakcji katolickiej (B 1994: 3) i protestanckiej (NT 1975: 1). Nie odnotowuje się go w żadnym z łużyckich przekładów. Zapis Jechonias zastosowano u Hórnika (NZ 1896: 1) i Frencla (SM 1960: 5), w tłumaczeniu zrewidowanym przez Jurija Jakuba występuje Jechoniafz (B 1905: 1). Odnotowuje się częściowe podobieństwo do czeskiego wariantu Jekoniáś (B 1613: 3).

(SP 2006: 1087) Šealtiel: splodźi [...] Šealtiela - (SP 1966: 17) Salatiel: splodźi [...] Salatiela;

(SP 2006: 1087) Šealtiel - (SP 1966: 17) Salatiel:

Antroponim Šealtiel w znacznej mierze odwołuje się do użytego w niemieckim przekładzie redakcji katolickiej imienia Schealtiël (B 1994: 3) oraz protestanckiego Shealthiel (NT 1975: 1), które zostało odnotowane także w tekście lużyckim z 1905 roku (B 1905: 1). Forma Salatiel z wcześniejszego tłumaczenia łużyckiego pokrywa się z imieniem w wersji Frencla oraz z identycznym czeskim (B 1613: 3); w znacznym stopniu zachowuje podobieństwo w stosunku do wariantu Hórnika - Salathiel (NZ 1896: 1).

(SP 2006: 1087) Serubbabel: spłodźi Serubbabela - (SP 1966: 17) Zorobabel: spłodźi Zorobabela;

(SP 2006: 1087) Serubbabel - (SP 1966: 17) Zorobabel:

Forma Serubbabel występuje w niemieckim przekładzie redakcji katolickiej (B 1994: 3); w stosunku do odnotowanej w wersji protestanckiej (Serubabel) (NT 1975: 1) zachodzi znaczne podobieństwo łużyckiej formy z 2006 roku. Antroponim Zorobabel ma tożsame odpowiedniki w thumaczeniach Hórnika (NZ 1896: 1), tekście lużyckim z 1905 roku (B 1905: 1) i czeskim (B 1613: 3) (Zorobábel).

(SP 2006: 1087) Abihud: spłodźi Abihuda - (SP 1966: 17) Abiud: spłodźi Abiuda; (SP 2006: 1087) Abihud - (SP 1966: 17) Abiud:

Antroponim Abihud jest tożsamy tylko z występującym w niemieckim przekładzie redakcji katolickiej (B 1994: 3). W wersji protestanckiej (NT 1975: 1), tłumaczeniu Hórnika 
(NZ 1896: 1), Frencla (SM 1960: 5), tekście łużyckim zrewidowanym przez Jurija Jakuba (B 1905: 1) i czeskim (B 1613: 3) odnotowana jest identyczna forma Abiud.

(SP 2006: 1087) Eljakim: spłodźi Eljakima - (SP 1966: 17) Eliakim: spłodźi Eliakima; (SP 2006: 1087) Eljakim - (SP 1966: 17) Eliakim:

Zapis imienia Eljakim występuje jedynie w niemieckim tłumaczeniu redakcji katolickiej (B 1994: 3). Forma Eliakim pojawia się w wersji protestanckiej (NT 1975: 1), we wszystkich analizowanych przekładach łużyckich (NZ 1896: 1, SM 1960: 5) oraz w Ewangelii czeskiej (B 1613: 3).

(SP 2006: 1087) Acor: spłodźi Acora - (SP 1966: 17) spłodźi Azora;

(SP 2006: 1087) Acor - (SP 1966: 17) Azor:

Imię Acor znajduje się jedynie w thumaczeniu Frencla (SM 1960: 5). W przekładach niemieckich odnotowano formy Asor (redakcja protestancka (NT 1975: 1)) i Azor (redakcja katolicka (B 1994: 3)), które występuje w pozostałych tłumaczeniach łużyckich (Hórnik (NZ 1896: 1), tekst łużycki z 1905 roku (B 1905: 1)) oraz czeskim (B 1613: 3).

(SP 2006: 1087) Cadok: spłodźi Cadoka - (SP 1966: 17) Sadok: spłodźi Sadoka; (SP 2006: 1087) Cadok - (SP 1966: 17) Sadok:

Forma Cadok nie występuje w żadnym spośród analizowanych tekstów Ewangelii według św. Mateusza. W obydwóch przekładach niemieckich (NT 1975: 1, B 1994: 3) zastosowano antroponim Zadok, który odnotowano również w tłumaczeniu łużyckim redakcji protestanckiej zrewidowanym przez Jurija Jakuba (B 1905: 1). Wersja Sadok zachowuje pełne podobieństwo w stosunku do Hórnika (NZ 1896: 1) i Frencla (SM 1960: 5); w znacznym stopniu zauważalne jest pokrewieństwo z czeskim Sádoch (B 1613: 3).

(SP 2006: 1087) Mattan: spłodźi Mattana - (SP 1966: 17) Matan: spłodźi Matana;

(SP 2006: 1087) Mattan - (SP 1966: 17) Matan:

Zachodzi pełna zgodność między formą użytą w niemieckim przekładzie redakcji katolickiej (B 1994: 3) a podaną w łużyckim przekładzie z 2006 roku (Mattan). Znaczne podobieństwo zauważalne jest w odniesieniu do niemieckiej redakcji protestanckiej (NT 1975: 1) - Matthan - która występuje również w protestanckim tłumaczeniu łużyckim zrewidowanym przez Jurija Jakuba (B 1905: 1). Te z kolei różnią się jedynie podwojonym $t$ od wersji Hórnika (Mathan) (NZ 1896: 1). Antroponim Matan odnotowano jedynie w przekładzie Frencla (SM 1960: 5) i w wydaniu czeskim - Mátan (B 1613: 3).

(SP 2006: 1088) Immanuel - (SP 1966: 18) Emanuel:

Antroponim Immanuel w tożsamej postaci występuje w protestanckim tłumaczeniu łużyckim z 1905 roku (B 1905: 4). Znaczne podobieństwo zachodzi w stosunku do niemieckiego przekładu redakcji katolickiej (B 1994: 4) (Immanuël) oraz wersji Frencla (SM 1960: 6) (Imanuel). W żadnym $\mathrm{z}$ analizowanych fragmentów nie występuje forma poświadczona w Swjatym Pismie z 1966 roku, to jest: Emanuel. Zachodzi jednak znaczne podobieństwo w stosunku do wersji Hórnika (NZ 1896: 3) i tekstu czeskiego (B 1613: 3) oraz niemieckiego redakcji protestanckiej (NT 1975: 1) - Emmanuel. 
(SP 2006: 1088) Jeremija: profeta Jeremiju - (SP 1966: 20) Jeremias: profeta Jeremiasa:

W antroponimie Jeremija zachodzi podobieństwo do niemieckiego przekładu redakcji katolickiej (B 1994: 4) i protestanckiej (NT 1975: 3) (Jeremia). Analogiczna forma nie występuje w przekładach łużyckich czy czeskim. Imię Jeremias odnotowano u Hórnika (NZ 1896: 3), Frencla SM 1960: 8). W thumaczeniu protestanckim (zrewidowanym przez Jurija Jakuba (B 1905: 5)) znajduje się Jeremiafz, natomiast w czeskim (B 1613: 4) bardzo podobna forma Jeremiáś.

(SP 2006: 1089) Rahel - (SP 1966: 20) Rachel:

Imię Rahel występuje w przekładzie niemieckim redakcji zarówno katolickiej (B 1994: 4), jak i protestanckiej (NT 1975: 3) oraz u Frencla (SM 1960: 8) i w thumaczeniu protestanckim z 1905 roku (B 1905: 5). Zapis Rachel znajduje się u Hórnika (NZ 1896: 3) oraz w tekście czeskim (B 1613: 4): Ráchel.

(SP 2006: 1089) Archelaus - (SP 1966: 20) Archelaos:

Antroponim Archelaus występuje w obydwóch tłumaczeniach niemieckich (B 1994: 4, NT 1975: 3), u Hórnika (NZ 1896: 3), Frencla (SM 1960: 8) i w tekście czeskim (B 1613: 4). W przekładzie protestanckim z 1905 roku (B 1905: 4) zastosowano zapis Archelaufz. Imię Archelaos nie zostało odnotowane w żadnym z pozostałych analizowanych przekładów.

(SP 2006: 1090) Cebedejoweho syna - (SP 1966: 23) Zebedejoweho syna;

(SP 2006: 1090) Cebedej: Cebedejom - (SP 1966: 23) Zebedej: Zebedejom;

(SP 2006: 1097) Cebedejowy syn - (SP 1966: 37) Zebedejowy syn:

(SP 2006: 1110) Cebedejoweju - (SP 1966: 64) Zebedejoweju

Formy użyte w najnowszym łużyckim wydaniu redakcji katolickiej są zbieżne z użytymi przez Frencla (SM 1960: 12) i nie występują w żadnym innym tłumaczeniu. Zapis Zebedejoweho syna jest najbliższy przekładowi protestanckiemu z 1905 roku (B 1905: 7) (Zebedeoweho) i dość podobny do czeskiego syna Zebedeova (B 1613: 6) u Hórnika (NZ 1896: 5) nie występuje przymiotnik dzierżawczy, lecz forma syna Zebedeja. Natomiast zapis Zebedejom (od Zebedej) w przekładzie z 1966 roku jest tożsamy z użytym przez Hórnika (NZ 1896: 5). W wersji zrewidowanej przez Jurija Jakuba występuje forma Zebedeom; w czeskim tekście (B 1613: 6) - Zebedeem. Z kolei forma mianownikowa Cebedejowy syn pokrywa się z użytą w thumaczeniu protestanckim z 1905 roku (B 1905: 7), Frencla i Hórnika. W przekładach niemieckich antroponim brzmi Zebedäus (B 1994: 6, NT 1975: 5).

(SP 2006: 1093) Salomo- (SP 1966: 29) Salomon:

Imię Salomo występuje w przekładach niemieckich, zarówno redakcji katolickiej (B 1994: 8), jak i protestanckiej (NT 1975: 9). Antroponim Salomon został użyty w przekładzie Hórnika (NZ 1896: 9) i protestanckim z 1905 roku (B 1905: 11). Frencel (SM 1960: 19) ma w tym miejscu Solomon, natomiast w tekście czeskim (B 1613: 8) jest to Šalomoun. 
(SP 2006: 1114) Izaakowy - (SP 1966: 71) Isaakowy:

Antroponim Izaak: Izaakom występuje w thumaczeniu Frencla (SM 1960: 22) i zachowuje częściowe podobieństwo do wersji czeskiej (B 1613: 10) - Izákem. W pozostałych wydaniach poświadczone są formy Isaakom (Hórnik (NZ 1896: 12)), Ifaakom (przekład protestancki z 1905 roku (B 1905: 13)) oraz Isaak (teksty niemieckie (B 1994: 11, NT 1975: 11)).

(SP 2006: 1090) Jezaja - (SP 1966: 32) Isaias;

(SP 2006: 1095) Jezaju - (SP 1966: 32) Isaiasa;

(SP 2006: 1101) Jezajowe - (SP 1966: 47) Isaiasowe:

Antroponim Jezaju (forma w bierniku 1.poj.) wydaje się zachować podobieństwo względem niemieckiego Jesaja (wariant katolicki (B 1994: 11) i protestancki (NT 1975: 11)). Tłumaczenie z 1905 roku (B 1905: 13) Jezajafza czy Frencla (SM 1960: 23) Jezajasa można umiejscowić pomiędzy porównywanymi łużyckimi formami Jezaju a Isaiasa. Względem tej drugiej całkowite podobieństwo zachodzi ze strony wersji Hórnika (NZ 1896: 12) (Isaiasa) i częściowe tekstu czeskiego B 1613: 10): Izaiáše.

(SP 2006: 1097) Bartrolm - (SP 1966: 37) Batrolm:

Spośród wszystkich analizowanych przekładów Biblii w ani jednym nie występuje antroponim Bartrotm i Batrotm. Najbliższa jest im forma w przekładzie Frencla (SM 1960: 28) (Bartrom) i Hórnika (NZ 1896: 15) (Bartrom). W tłumaczeniach niemieckich obydwóch redakcji (b 1994: 13, NT 1975: 14) zastosowano zapis Bartholomäus, bliski temu jest Bartholomej w wersji protestanckiej z 1905 roku (B 1905: 16). W tekście czeskim (B1613: 12) występuje Bartoloměj.

(SP 2006: 1098) Beelcebul: Beelcebula - (SP 1966: 39) Belcebub: Belcebuba:

Forma Beelcebula jest najbliższa thumaczeniu Frencla (SM 1960: 29) - Beelcebuba. Zapis z podwojoną literą $e$ występuje również w thumaczeniu z 1905 roku (B 1905: 17) (Beelzebub) oraz u Hórnika (NZ 1896: 16) (również Beelzebub), jednak podobieństwo analizowanej formy jest względem nich mniejsze. Taki zapis występuje również w thumaczeniu niemieckim redakcji protestanckiej (NT 1975: 15), natomiast w katolickiej antroponim ten nie występuje w ogóle, zamiast niego thumaczy się Satan (B 1994: 13). Tekst czeski (B 1613: 12) podaje formę Belzebubem.

(SP 2006: 1099) Elija - (SP 1966: 40) Elias:

(SP 2006" 1106) Eliju - (SP 1966: 55) Eliasa:

(SP 2006: 1107) Eliji - (SP 1966: 56) Eliasej:

Antroponim Elija występuje w thumaczeniu niemieckim redakcji katolickiej (B 1994: 15); w protestanckim jest nieznacznie zmieniony - Elja (NT 1075: 23). Zapis Elias jest identyczny z formami udokumentowanymi w przekładach Frencla (SM 1960: 51) oraz Hórnika (NZ 1896: 29). W przekładzie czeskim (B 1613: 20) zastosowano antroponim Eliáš. Podobny zapis jest poświadczony w thumaczeniu z 1905 roku (B 1905: 29) Eliajz.

(SP 2006: 1099) Choracinje - (SP 1966: 41) Chorazinje: 
Forma wołacza Choracinje nawiązuje jedynie do thumaczenia Frencla (SM 1960: 32): Choracimje. Podobna forma występuje w thumaczeniu z 1905 roku (B 1905: 18): Chorazim. Zapis Chorazinje zachowuje największe podobieństwo względem przekładów niemieckich obydwóch redakcji (B 1994: 15, NT 1975: 17) - Chorazin. Antroponim przyjęty przez Hórnika (NZ 1896: 18), Korozainje, odwołuje się do czeskiego Korozaim (B 1613: $14)$.

(SP 2006: 1101) Jona: Jony - (SP 1966: 44) Jonas: Jonasa;

(SP 2006: 1101) Jona - (SP 1966: 44) Jonas;

(SP 2006: 1101) Jonowe - (SP 1966: 44) Jonasowe:

Antroponim Jona występuje w niemieckim przekładzie redakcji katolickiej (B 1994: 17); w Biblii protestanckiej pojawia się Jonas. Ta forma występuje również w tłumaczeniach Hórnika (NZ 1896: 21), Frencla (SM 1960: 36); w wydaniu z 1905 roku (B 1905: 21) zastosowano zapis Jonafz. W tekście czeskim (B 1613: 15) imię brzmi Jonášs.

(SP 2006: 1115) Cacharias: Cachariasa - (SP 1966: 74) Zacharias: Zachariasa:

Antroponim Cacharias nie występuje w żadnym z analizowanych przekładów. W niemieckim redakcji katolickiej (B 1994: 35) zastosowano formę Secharja, występuje minimalne podobieństwo względem przekładu zrewidowanego przez Jurija Jakuba (B 1905: 40) - Sachariafza. Frencel (SM 1960: 71) w tym miejscu wprowadza Sachariasa. Tłumaczenie Ewangelii wg św. Mateusza z 1966 roku zachowuje formę tożsamą z przekładem Hórnika (NZ 1896: 41) i tekstem czeskim B 1613: 28): Zachariáše. Forma Zachariasa jest tożsama z niemieckim wariantem protestanckim Zacharias (NT 1975: 38).

(SP 2006: 1118) Kajfas - (SP 1966: 81) Kaifas;

(SP 2006: 1121) Kajfasej - (SP 1966: 85) Kaifasej:

Zapisy Kajfas oraz Kajfasej są tożsame z thumaczeniem Frencla (SM 1960: 79) i zachowują częściowe podobieństwo względem tekstu z 1905 roku (B 1905: 44) (Kaiphas, Kaiphafzej). Formy Kaifas i Kaifasej występują u Hórnika (NZ 1896: 45), nawiązują do niemieckiego przekładu redakcji protestanckiej (NT 1975: 42) - Kaiphas - i czeskiego (B 1613: 28) (Kaifáš). W katolickim tłumaczeniu niemieckim (B 1994: 34) antroponim ma postać Kajaphas.

(SP 2006: 1121) Barabbas - (SP 1966: 87) Barabas;

(SP 2006: 1121) Barabbasa - (SP 1966: 87) Barabasa:

Formę Barabbas spotyka się w większości analizowanych przekładów: w niemieckim redakcji katolickiej (B 1994: 37) i Biblii protestanckiej (NT 1975: 46), Hórnika (NZ 1896: 49) oraz tekście z 1905 roku (B 1905: 48) z jedną różnicą w zapisie (Barabbafz). Antroponim Barabas występuje w thumaczeniu Frencla (SM 1960: 86) i w przekładzie czeskim (B 1613: 34) (także z jedną różnicą w zapisie wygłosu - Barabáś). 


\subsubsection{Toponimy}

(SP 2006: 1088) do Egyptowskeje - (SP 1966: 19) do Egiptowskeje;

(SP 2006: 1088) z Egyptowskeje - (SP 1966: 19) z Egiptowskeje;

(SP 2006: 1089) w Egyptowskej - (SP 1966: 20) w Egiptowskej:

Formy Egyptowskeje, Egyptowskej mogą mieć swoje uzasadnienie w wariancie czeskim (B 1613: 4) (do Egypta, z Egypta, $v$ Egyptě) lub są inspirowane niemiecką pisownią (B 1994: 4, NT 1975: 2) - Ägypten. W pozostałych przekładach łużyckich redakcji katolickiej i protestanckiej (SM 1960: 7, B 1905: 4) występuje zapis do Egiptowskeje, z Egiptowskeje, w Egiptowskej.

(SP 2006: 1089) Nacaret - (SP 1966: 20) Nazaret;

(SP 2006: 1089) Nacaretski - (SP 1966: 20) Nazaretski:

(SP 2006: 1111) Nacareta - (SP 1966: 66) Nazareta:

(SP 2006: 1103) Nacareće ${ }^{4}$ - (SP 1966: 51) Nazareće:

Toponim Nacaret (i utworzony od niego przymiotnik) poświadczony w najnowszym wydaniu łużyckiej Biblii katolickiej, występuje jedynie w thumaczeniu Frencla (SM 1960: 9). Forma Nazaret jest zbieżna z zapisem w niemieckim przekładzie redakcji katolickiej (B 1994: 4) i w tekście czeskim (B 1613: 4) (Nazarét i Nazaretský). Widoczne jest znaczne podobieństwo do niemieckiego (NT 1975: 3) i łużyckiego wariantu protestanckiego z 1905 roku (B 1905: 5) oraz Hórnika (NZ 1896: 3) (Nazareth, ale Nazarenski).

(SP 2006: 1090) Sebulon, Naftali: Sebulona a Naftalija - (SP 1996: 23) Zabulon, Neftalin: Zabulona a Neftalina;

(SP 2006: 1090) Sebulon - (SP 1996: 23) Zabulon;

(SP 2006: 1090) Naftali - (SP 1996: 23) Neftalin:

Zapis formy Sebulon i Naftalij oraz jej formy deklinacyjne są tożsame z zastosowanymi w przekładzie niemieckim redakcji katolickiej (B 1994: 5); w protestanckiej (NT 1975: 4) występuje identyczny zapis Sebulon, jednak nieco odmienny w stosunku do Naftalija Naphtali. Widoczne jest znaczne podobieństwo form Zabulon a Neftalin względem wersji Hórnika (NZ 1896: 5) (Zabulon a Neftalim), protestanckiej z 1905 roku (B 1905: 6) (Zabulona a Nefthalima) czy czeskiej (B 1613: 5) (Zabulon a Neftalím). W porównaniu z przekładem Frencla (SM 1960: 11) (Cebulon a Neftalim) tłumaczenie łużyckie z 1966 roku jest z nim zgodne jedynie w nazwie Neftalim.

(SP 2006: 1090) krajiny Dekapolis - (SP 1966: 23) krajiny Dźesać městow:

Toponim Dekapolis nie występuje w żadnym z analizowanych przekładów. Nazwę Dźesać městow zastosowano w przekładach Hórnika (NZ 1896: 5), w protestanckim z 1905 roku (B 1905: 7) odnotowuje się formę dźefzacź měftow. Frencel (SM 1960: 12) thumaczy w tym miejscu z Dźesaćiměstowskeje, a w tekście czeskim (B 1613: 6) widnieje zapis Desítivměst. W thumaczeniu niemieckim redakcji katolickiej (B 1994: 6) toponim ma for-

4 Toponim zawarty w tytule akapitu; tytulatura występuje jedynie w dwóch podstawowych analizowanych przekładach łużyckich Ewangelii wg św. Mateusza. 
mę aus dem Gebiet der Zehn Städte; w protestanckiej (NT 1975: 5) - dem Zehnstädtegebiet.

(SP 2006: 1097) Gomorrski kraj: Gomorrskemu krajej - (SP 1966: 37) Gomorskemu krajej:

Wyrażenie Gomorrski kraj ze względu na zapis przez podwojone $r$ zachowuje częściowe podobieństwo do tłumaczenia Hórnika (NZ 1896: 16) (zemi [...] Gomorrhskej) i do nazw występujących w niemieckich przekładach obydwóch redakcji (B 1994: 13, NT 1975: 14): Gomorra. Forma z 1966 roku jest tożsama z wersją Frencla (SM 1960: 28) i przekładem zrewidowanym przez Jurija Jakuba (B 1905: 16) (choć zastosowano inną: Gomorfkej zemi). Czeskie thumaczenie podaje zemi [...] Gomorských (B 1613: 12).

(SP 2006: 1104) Gennezar - (SP 1966: 51) Genezar;

(SP 2006: 1104) Gennezaretskeje - (SP 1966: 51) Genezaretskeje:

Forma Gennezar zachowuje największe podobieństwo względem niemieckiego przekładu redakcji katolickiej (B 1994: 20) (Gennesaret). W wersji protestanckiej (NT 1975: 23) toponim ma formę Genezareth, która jest tożsama z thumaczeniem z 1905 roku (B 1905: 25). Zapis w tłumaczeniu Frencla (SM 1960: 45) ma postać Genecaret. Czeski przekład (B 1613: 18) podaje (do) zemé Genezaretské, natomiast Hórnik (NZ 1896: 25) genezarethskeje krajiny.

\subsubsection{Przymiotniki od antroponimów}

(SP 2006: 1087) běše Urijowa - (SP 1966: 16) běše Uriasowa:

Forma Urijowa nawiązuje jedynie do niemieckiego przekładu redakcji katolickiej (B 1994: 3): seine Mutter war die Frau Urijas, częściowo redakcji protestanckiej (NT 1975: 1): Salomo von der (Frau) des Uria. Zapis běše Uriasowa odnosi się do identycznego, użytego przez Hórnika (NZ 1896: 1). W mniejszym stopniu zauważalne jest podobieństwo do tłumaczenia Frencla (SM 1960: 5) (spłodźi Solomona z Uriasowej), do tekstu łużyckiego zrewidowanego przez Jurija Jakuba (B 1905: 1) (s Uriašowej mandźelskej). Zachodzi jednak duże podobieństwo do czeskiego tłumaczenia (B 1613: 3) - byla Uriášova.

(SP 2006: 1105) kananejska - (SP 1966: 52) kananejska:

Forma przymiotnika kanaanejska odnosi się do form użytych w niemieckim tłumaczeniu redakcji katolickiej (B 1994: 21) (kanaanitische) oraz protestanckiej (NT 1975: 24) (kanaanäische). Zapis kananejska jest identyczny z przymiotnikami występującymi w przekładach Hórnika (NZ 1896: 19), Frencla (SM 1960: 46) oraz w tekście zrewidowanym przez Jurija Jakuba (B 1905: 21). Zachodzi duże podobieństwo do czeskiego tłumaczenia (B 1613: 18) - kananejská.

(SP 2006: 1111) dźowce Cionskej - (SP 1966: 66) dźowce sionskej:

Forma Cionskej jest tożsama z tłumaczeniem Frencla (SM 1960: 62) i nie zachowuje większego podobieństwa do pozostałych, z wyjątkiem (pod względem brzmienia) występującej w niemieckim przekładzie redakcji protestanckiej (NT 1975: 33): der Tochter Zion. 
W tłumaczeniu z 1905 roku (B 1905: 34) oraz Hórnika (NZ 1896: 35) występuje zapis Sionskej, w czeskim (B 1613: 25) - Sionské. W przekładzie niemieckim redakcji katolickiej (B 1994: 27) nie występuje forma podobna do powyższych, lecz (Sagt) der Stadt Jerusalem.

\section{Zakończenie}

Formy wyekscerpowane z tekstu Ewangelii wedtug świętego Mateusza dzielą się na trzy grupy: antroponimy, toponimy i przymiotniki od antroponimów. Istnieje zauważalna różnica pomiędzy formami użytymi w Swjatym Pismie Noweho zakonja z 1966 roku a udokumentowanymi w Swjatym Pismie Stareho a Noweho zakonja z 2006 roku.

Omówione w pracy antroponimy z łużyckiego wydania Biblii z 2006 roku są tożsame z formami użytymi w:

- tłumaczeniu niemieckim redakcji katolickiej w 49\%;

- tłumaczeniu niemieckim redakcji protestanckiej w 24\%;

- thumaczeniu Frencla w 17\%;

- tłumaczeniu czeskiego w 7\%;

- tłumaczeniu Hórnika oraz tłumaczeniu z 1905 roku w 5\%.

Przeanalizowane toponimy z łużyckiego wydania Biblii z 2006 roku są identyczne z formami użytymi w:

- tłumaczeniach niemieckich redakcji katolickiej i protestanckiej oraz w przekładzie Frencla w $17 \%$.

Przymiotniki od antroponimów są zbieżne z formami zapisanymi w:

- tłumaczeniu niemieckim redakcji katolickiej w 67\%;

- tłumaczeniu niemieckim redakcji protestanckiej oraz w przekładzie Frencla w 33\%.

Jak wynika z powyższego zestawienia, na kształt antroponimów, toponimów oraz przymiotników od antroponimów udokumentowanych w tekście Swjateho Pisma Stareho a Noweho zakonja (Budyšin 2006) największy wpływ miał przekład niemiecki redakcji katolickiej, w nieco mniejszym stopniu przekład protestancki oraz tłumaczenie Frencla.

Omówione antroponimy z łużyckiego wydania Biblii z 1966 roku są tożsame z formami użytymi w:

- tłumaczeniu Hórnika w 59\%;

- tłumaczeniu Frencla w 34\%;

- thumaczeniu z 1905 roku w 22\%;

- tłumaczeniu czeskim w 20\%;

- tłumaczeniu niemieckim redakcji protestanckiej w 15\%;

- tłumaczeniu niemieckim redakcji katolickiej w 5\%.

Przeanalizowane toponimy z łużyckiego wydania Biblii z 1966 roku są identyczne z formami użytymi w:

- thumaczeniu z 1905 roku w 50\%;

- tłumaczeniach Frencla i Hórnika w 33\%. 
Przymiotniki od antroponimów są zbieżne z formami zapisanymi w:

- thumaczeniu Hórnika w 100\%;

- thumaczeniu z 1905 roku w 67\%;

- thumaczeniu Frencla w 33\%.

$\mathrm{Z}$ zestawienia wynika, iż na formę antroponimów, toponimów oraz przymiotników od antroponimów, udokumentowanych w łużyckim wydaniu Biblii z 1966 roku, największy wpływ miało tłumaczenie Hórnika, nieco mniejszy przekład z 1905 roku oraz tekst Frencla.

\section{Źródła}

B 1613 - Bible svatá aneb všecka svatá písma starého i nowého zakona, podle posledního vydání kralického z roku 1613.

NZ 1896 - Nowy zakoń, przeł. J. Łusčanski, M. Hórnik, Budyšin 1896.

B 1905 - Biblia, to je Zyłe Sswjate Pifzmo Jtareho a noweho fakonja, Budyšin 1905.

SM 1960 - Sćenje po swjatym Mateju, Budyšin 1960.

SP 1966 - Swjate Pismo Noweho zakonja, Budyšin 1966.

NT 1975 - Das neue Testament, Revidierte Erbelfelder Übersetzung, Wuppertal 1975.

B 1994 - Die Bibel im heutigem Deutsch. Die Gute Nachricht des Alten und Neuen Testaments, Liechtenstein 1994.

SP 2006 - Swjate Pismo Stareho a Noweho zakonja, Budyšin 2006.

\section{Bibliografia}

Basaj M., 1993, O antroponimach w przekładach z języków blisko spokrewnionych, w: Onomastyka literacka, red. M. Biolik, Olsztyn, s. 337.

Ginter A., 2008, O przekładzie nazw osobowych w rosyjskojęzycznej wersji „Chłopów” Władysława Stanistawa Reymonta, „Folia Linguistica Rossica” 4, s. 39-52.

Kamińska M., 1993, Onomastyka biblijnych tekstów przekładowych jako problem badawczy, w: Onomastyka literacka, red. M. Biolik, Olsztyn, s. 321-327.

Kania S., Tokarski J., 1984, Onomastyka, w: Zarys leksykologii i leksykografii, Warszawa, s. 197-201.

Klawek A., 1938, Psałterz: nowy przektad tekstu Wulgaty, Lwów.

Lewaszkiewicz T., 1995, Łużyckie przekłady Biblii. Przewodnik bibliograficzny, Warszawa, s. 5-47;

Lewaszkiewicz T., 1998, Partykularyzm religijny na Górnych Łużycach a historia górnołużyckiego języka literackiego, w: Serbołużyczanie - Łużyce: badania historyczne i fascynacje, red. T. Jaworski i W. Pyżewicz, Zielona Góra, s. 87-93;

Onomastyka literacka, 1993, red. M. Biolik, Olsztyn.

Siatkowska E., Meškank T., 2001, O języku Łużyczan prawie wszystko, Warszawa.

Umińska-Tytoń E., 1993, Nazwy osobowe $w$ tzw. dynamicznym przekładzie Nowego Testamentu, w: Onomastyka literacka, red. M. Biolik, Olsztyn, s. 329. 


\section{JOANNA WALISZEWSKA}

\section{Anthroponyms and Toponyms in Sorbian Translations of The Gospel According to St. Matthew}

\section{Summary}

The article is devoted to the analysis and description of anthroponyms and toponyms occurring in Catholic Upper-Sorbian translations of The Gospel According to St. Matthew. The excerpted forms have been compared with one another as well as with the forms encountered in various translations: the Protestant Upper-Sorbian, the Czech, the German (Catholic and Protestant). The study is composed of the historical outline of the Sorbian translations of the Bible and the analysis of different linguistic manifestations of proper names in the Catholic editions of The Gospel According to St. Matthew.

Keywords: Bible translations; Biblical anthroponymy; Biblical toponymy; Upper-Sorbian translations of the Bible; Catholic translation; Protestant translation, The Gospel According to St. Matthew. 
